\title{
Kısıntılı Sulama Altında Hibrit Mısır Çeşitlerinin Bazı Büyüme Parametreleri Üzerine Bir Sera Çalışması
}

\author{
Mertay DEMIR ${ }^{1}$, Alkhan SARIYEV ${ }^{1, *}$, Mert ACAR $^{1}$, Sertan SESVEREN ${ }^{2}$, \\ Taofeek Samuel WAHAB ${ }^{1}$ \\ ÖZ
}

Tarımsal üretimde su stresine toleranslı ve verim potansiyeli yüksek hibrit tohumların kısıntılı sulamaya verdiği tepki oldukça önemlidir. Bu çalışmada sera koşullarında saksıda, kısıntılı sulamanın Çukurova bölgesinde verim kapasitesi yüksek hibrit mısır (P2088 ve P1921) çeşitlerinin bazı bitki gelişim parametreleri üzerine etkileri belirlenmiş̧ir. Denemede $\mathrm{I}_{100}$ (tarla kapasitesinde sulama), $I_{75}$ ve $I_{50}$ ( $I_{100}$ uygulamasinda verilen suyun sirasiyla $\% 75^{\prime} i$ ve $\% 50$ 'si) olmak üzere üç farklı sulama düzeyi incelenmiştir. Toprak su içeriği arttıkça bitki boyu ve kuru madde miktarı önemli şekilde artmıştır. P2088 ve P1921 çeşitleri için sırasıyla en yüksek bitki boyu ve kuru madde miktarlar1 $42.81 \mathrm{~cm}, 46.08 \mathrm{~cm}$ ve $26.7 \mathrm{~g} \mathrm{saks1}^{-1}, 27.9 \mathrm{~g} \mathrm{saks1}^{-1}$ ile $\mathrm{I}_{100}$ uygulamasında elde edilmiştir. Mısır bitkisinin üst aksamında farklı sulama düzeylerinin P2088 (potasyum içeriği hariç) ve P1921 mısır çeşitlerinde tüm makro elementler üzerinde istatistiksel olarak önemli etkileri bulunmamıştır. Sulama miktarı azaldıkça bitkinin makro besin elementi alımı da azalmıştır. Çalışmada bulgular, $\mathrm{I}_{100}$ 'e göre $\% 25$ su tasarrufu sağlayan $\mathrm{I}_{75}$ uygulamasının daha uzun yetiştiricilik periyodunda denenmesini destekler niteliktedir. Böylelikle, daha fazla alanın sulama olanağı ve mısır bitkisinin su kullanım etkinliğinin artabileceği ortaya konulmuştur.

Anahtar Kelimeler: Kısıntılı sulama, mısır, çeşit, büyüme parametreleri, Çukurova bölgesi.

\section{A Greenhouse Study on Some Growth Parameters of Hybrid Corn Varieties under Deficit Irrigation}

\begin{abstract}
The response of hybrid seeds tolerant to water stress and high yield potential to deficit irrigation is very important in agricultural production. In this study, the effects of deficit irrigation on some plant growth parameters of hybrid corn (P2088 and P1921) varieties with high yield capacity in pots were determined under greenhouse conditions. Three different irrigation levels were examined as $\mathrm{I}_{100}$ (irrigation at field capacity), $\mathrm{I}_{75}$ and $\mathrm{I}_{50}(75 \%$ and $50 \%$ of the water given in the I100 treatment, respectively) in the experiment. As the soil moisture increase, plant height and the biomass increased in significant amounts. The highest plant height and biomass were obtained in $\mathrm{I}_{100}$ treatment with $42.81 \mathrm{~cm}, 46.08 \mathrm{~cm}$ and $26.7 \mathrm{~g} \mathrm{pot}^{-1}, 27.9 \mathrm{~g} \mathrm{pot}^{-1}$ for $\mathrm{P} 2088$ and P1921, respectively. There were no statistically significant effects of different irrigation regimes on all macro elements in P2088 (except for potassium content) and P1921 corn varieties on the upper part of the corn plant. As the irrigation amount reduces, the uptake of macro elements by plants also reduces. The findings in the study support the trial of I75 treatment, which saves $25 \%$ water compared to $\mathrm{I}_{100}$, in a longer growing period. Thus, the irrigating capability of wider area of land and water use efficiency of corn crop can be increased.
\end{abstract}

Keywords: Deficit irrigation, corn, variety, growth parameters, Çukurova region.

ORCID ID (Yazar sirasına göre)

0000-0002-5711-4901, 0000-0003-2832-0113, 0000-0002-9971-4470, 0000-0002-5163-7066, 0000-0001-9192-5946

\footnotetext{
Yayın Kuruluna Geliş Tarihi: 11.11.2021

Kabul Tarihi: 28.12.2021

${ }^{1}$ Çukurova Üniversitesi, Ziraat Fakültesi, Toprak Bilimi ve Bitki Besleme Bölümü, Adana, Türkiye.

${ }^{2}$ Kahramanmaraş Sütçü İmam Üniversitesi, Ziraat Fakültesi, Biyosistem Mühendisliği Bölümü,

Kahramanmaraş, Türkiye

*E-posta: asariyev@cu.edu.tr
} 


\section{Kısıntılı Sulama Altında Hibrit Mısır Çeşitlerinin Bazı Büyüme Parametreleri Üzerine Bir Sera Çalışması}

\section{Giriş}

Günümüzde yaşanan iklim değişikliği sebebiyle mevcut su kaynaklarının azalmasına karşıllk enerji talebinin, nüfusun, sanayi ve insan tüketiminde kullanılan su miktarının sürekli olarak artması tarımsal üretimde kullanılacak olan su miktarının azalmasına sebep olmaktadır. $\mathrm{Bu}$ nedenle su kullanımında acil ve ciddi tedbirler alınmalıdır. Alınan tedbirler arasında tarımda su kullanımını azaltacak, birim alandan daha çok verim alınmasını sağlayacak yöntemler üzerine durulmalıdır. Diğer taraftan suyun kıt olduğu bölgelerde tarımı yapılacak olan bitkiler kuraklığa direnç gösteren çeşitlerden seçilmelidir.

Tarımsal üretimde su, bitki gelişimi için gerekli temel unsurlardan birisidir. Misır bitkisi gibi yüksek düzeyde suya ihtiyaç duyan bitkiler için yetişme ortamında yeterli su olmayınca bitkinin fizyolojik süreçleri kısıtlanmakta ve bitkinin verimliliğini azaltmaktadır (Bozkurt ve ark., 2006). Bu durumu bilen çoğu çiftçiler ise yüksek mısır verimliliğine ulaşmaları için bitkinin ihtiyaç duyduğu su miktarından daha fazlasını vermekte ve ortaya çıkan düşük su kullanım etkinliği zarara neden olmaktadır (Zhang ve ark., 2017). Ancak yüksek tarımsal sulama hedefi, bitki başına kullanılan su kullanım etkinliğinin olası en yüksek düzeye çıkarılması ve bitkisel üretim için en uygun kullanılabileceği su rejimini bulmaktır (Zhang ve ark., 2008). Sulanan tarım alanları, tatlı suyun \%70-75'ini kullanmakta ve bu da sürekli olarak artma eğiliminde olan dünya nüfusu ve giderek daha çok hissedilen iklim değişikliği nedeniyle tatlı su üzerinde ciddi baskı yapmaktadır. Bu nedenle, kısıntılı sulama, su kaynakları kısıtlı veya kuraklığa meyilli bölgeler için bir uyum stratejisi olarak dikkate alınmaktadır (Afzal ve ark., 2018).

Tarımsal üretimde kullanılan geleneksel kısıntılı sulama, ürün veriminde önemli azalışa sebep olmadan kullanılan suyun miktarını azaltan yaklaşımlardan biridir (Chai ve ark., 2016). Bu teknik, sulama etkinliğini artırdığı gibi çiftçilerin kazançlarını da artıran bir uygulamadır (Fereres ve Soriano, 2007). Buna karşın, kısıntılı sulamanın etkili kullanımı; sulama suyuna bitki tepkisinin az olduğu bitki gelişme dönemlerini, bitki su verim ilişkilerini ve üretim maliyetini bilmeyi gerektirir. Moutonnet (2004) de bitki gelişiminin belirli bir döneminde yapılacak olan kısıntının bitkinin o büyüme dönemindeki hassasiyetine bağlı olarak verimi etkilediğini belirtmiştir.

Kısıntılı sulama altındaki bitkiler, bir miktar su stresi yaşar ve genellikle tam sulanan bitkilerden daha düşük verime sahiptirler (Lopez ve ark., 2017). Kısıntılı sulama koşulları altında \% 20-40 arasında sulama suyu tasarrufuna karşı11k \% 10'un altındaki verim azalması gerçekleşebilir (Kögler ve Söffker, 2017). Pek çok bitkide maksimum su verimliliği ya da su kullanım verimliliği (WUE) elde etmek için sulama stratejileri belirlenir. $\mathrm{Bu}$ amaçla farklı su uygulamalarına karșı olarak gösterilen ürün tepkileri kullanılmıștır. Su açığına bitkinin duyarlılığı, iklim koşulları, bitki türleri ve çeşitleri ve tarımsal yönetim uygulamaları gibi birçok faktörden etkilenebilir. Bazı bitkilerde oluşturulan kısıntılı sulama oranlarının verim kayb1 ve yüksek sulama suyu kullanım verimliliği ile sonuçlanmadığını (Patanè ve ark., 2011), ya da bitki verimini olumsuz etkilemeden su tasarrufu sağlandığı görülmüştür (Abd ElWahed ve ark., 2017; Samperio ve ark., 2015). Yüksek düzeyde suya ihtiyaç duyan misır bitkisinin verimliliğini çok fazla azaltmadan kısıntılı sulama üzerinde çeșitli araștırmalar bulunmaktadır (Pereira ve ark., 2012, Zhang ve ark., 2017).

Misır bitkisi, tropik, subtropik ve 1lıman iklim koşullarında yetişen bir bitki olduğu için dünyanın hemen hemen tüm bölgelerinde tarımı yapılabilmektedir (Kırtok, 1998). Birleşmiş Milletler Gıda ve Tarım Örgütü (FAO) verilerine göre 2018 yılında dünya toplam mısır ekim alanı 193 milyon hektarın, üretimi ise 1.1 milyar tonun üzerine çıkmış ve ekim alanı olarak buğdaydan sonra misır, üretim yönünden ikinci sırada yer almıştır. Türkiye'de ise 2018 yılında mısır ekim alan1 591 bin hektar, üretimi 5.7 milyon ton, ortalama verim ise $964 \mathrm{~kg} \mathrm{da}^{-1}$ olmuştur (Anonim, 2021a). Sulama olanaklarının artması, sulama sistemlerinin gelişmesi, hibrit tohum kullanımının yaygınlaşması, yüksek verimli çeşitlerin geliştirilmesi ve üretim tekniklerinin iyileştirilmesiyle Türkiye'de misır üretim ve verim ortalaması artış göstermiştir. Türkiye'de mısır üretimi, 2019/20'de yeniden 6 milyon tona 


\section{Kısıntıı Sulama Altında Hibrit Mısır Çeşitlerinin Bazı Büyüme Parametreleri Üzerine Bir Sera Çalışması}

çıkmıştır. 2020/21'de ise 2015/2016'daki 6.4 milyon tonluk seviye de aşılarak 6.5 milyon tona ulașılmıştır (Anonim, 2021b). Tarım ve Orman Bakanlığının sitesinde yer alan rapora göre Çukurova bölgesinde, ana üründe (FAO 650750) 120-135 günlük, ikinci ürün misır yetiştiriciliğinde ise erkenci ve orta erkenci olum grubuna giren (FAO 550-650) 105-115 günlük çeşitlerin seçimi daha uygundur. Koçan kabuğu ucu kapalı, yatmaya dayanıkl1, zararlı ve hastalıklara dayanıklı, hasat esnasında tanedeki rutubet \% 25'in altında, sicağa toleransı iyi ve verim (Koçanda 500-600 dane iyi bir verim demektir) yüksek olmalıdır (Anonim, 2021c). Suyun bitki gelişimini sınırlayan en önemli faktör olduğunu göz önünde bulundurarak, kısıtlı sulama ve verim ilişkilerinin araştırılması amaciyla Pioneer Tohumculuk Dağıtım ve Pazarlama Ltd. Şti. ait su stresine toleransl, verim potansiyeli yüksek Çukurova bölgesinde yoğun olarak yetiştiriciliği yapılan mısır çeşitleri P1921 ve P2088 bölge çiftçisine arz edilmektedir. $\mathrm{Bu}$ çerçevede çalışmanın amacı verimli olduğu düşünülen bu iki mısır çeşidinin sera koșullarında farklı sulama düzeylerinin bazı gelişim parametreleri üzerine etkilerinin araştırılması olmuştur.

\section{Materyal ve Yöntem}

Çalışma Çukurova Üniversitesi, Ziraat Fakültesi, Toprak Bilimi ve Bitki Besleme Bölümü seralarında iki adet tescil edilmiş verimliliği yüksek olan P2088 ve P1921 misır çeşitlerinin kısıtlı sulamayı içeren üç farklı sulama düzeyinin $\left(\mathrm{I}_{100}\right.$ tam sulama, $\mathrm{I}_{75}$ ve $\mathrm{I}_{50}$ kısıntılı sulama) bitki gelişim parametrelerine olan etkilerini araştırmak için yürütülmüştür.

Denemede Çukurova Üniversitesi, Ziraat Fakültesi, Araştırma ve Uygulama Çiftliği arazilerinde bulunan ve toprak taksonomisine göre Typic Haploxerert olarak tanımlanan, kil içeriği yükssek Arık serisinden (Gülez ve Şenol, 2002) alınan topraklar kullanılmıştır. Toprağın tanımlayıcı analizleri yapılmıştır. Tekstür hidrometre yöntemi ile belirlenmiştir (Bouyoucos, 1962). Toprak pH's1 ve elektriksel iletkenlik, 1:2.5 oranında sulandırılmış örneklerde $\mathrm{pH}$ ve EC metre okumaları ile belirlenmiştir (McLean, 1982). Kireç Scheibler kalsimetresi ile karbondioksit çıkış hacmi dikkate alınarak belirlenmiştir (Kacar, 1994). Organik madde modifiye edilmiş Walkley-Black metodu ile belirlenmiștir (Nelson ve Sommers, 1982). Yarayışlı fosfor, sodyum, bikarbonat metodu ile (Olsen ve ark., 1954), ekstrakte edilebilir potasyum $1 \mathrm{~N}$ amonyum asetat ile ekstraksiyonda (Thomas, 1982), demir, çinko, bakır ve mangan DTPA (Lindsay ve Norwell, 1978) ile belirlenmiştir. Çalışmada kullanılan toprağa ait bazı fiziksel ve kimyasal özellikler Çizelge 1'de verilmiştir.

Çizelge 1. Denemede kullanılan toprağın bazı fiziksel ve kimyasal özellikleri

\begin{tabular}{lc}
\hline Özellik & Değer \\
\hline Kil, \% & 54.8 \\
Silt, \% & 27.7 \\
Kum, \% & 17.5 \\
Bünye Sınıfı & Kil \\
pH $(1: 2.5)$ & 8.50 \\
EC $(1: 2.5)$, mmhos.cm ${ }^{-1}$ & 0.23 \\
Kireç, \% & 29.1 \\
Organik Madde, \% & 1.20 \\
Fosfor, mg.kg-1 & 14.99 \\
Potasyum, mg.kg-1 & 414.4 \\
Bakı, mg.kg-1 & 1.46 \\
Çinko, mg. $\mathrm{kg}^{-1}$ & 0.55 \\
Demir, mg.kg-1 & 6.43 \\
Mangan, ${\mathrm{mg} . \mathrm{kg}^{-1}}^{-1}$ & 10.37 \\
\hline
\end{tabular}

Toprağın tarla kapasitesi (TK) ve solma noktası (SN) düzeyleri ise basınçlı plakalar sisteminde belirlenmiştir (Klute, 1986).

Arık serisinde 0-30 $\mathrm{cm}$ derinlikte toprak örneği 4 mm'lik elekten elenmiş ve her saksıya hava kurusu olmak üzere $5 \mathrm{~kg}$ toprak konulmuştur. Deneme, 4 tekerrürlü olarak tesadüf parselleri deneme desenine göre yürütülmüştür. Temel gübreleme olarak saksılara başlangıçta $\mathrm{Ca}\left(\mathrm{NO}_{3}\right)_{2}$ formunda $200 \mathrm{mg} \mathrm{kg}^{-1} \mathrm{~N}, \mathrm{KH}_{2} \mathrm{PO}_{4}$ formunda 100 $\mathrm{mg} \mathrm{kg}{ }^{-1} \mathrm{P}, \mathrm{ZnSO}_{4}$ formunda $5 \mathrm{mg} \mathrm{kg}^{-1} \mathrm{Zn}, \mathrm{CaSO}_{4}$ formunda $50 \mathrm{mg} \mathrm{kg}^{-1} \mathrm{~S}$, ve Fe-EDTA formunda $5 \mathrm{mg} \mathrm{kg}^{-1} \mathrm{Fe}$ uygulanmıştır.

Denemede $I_{100}$ tam sulama uygulamas1 olup, toprağın tarla kapasitesine (TK) kadar sulandığ 1 (iki sulama arasında saksida eksilen suyun TK'ya getirildiği düzey) uygulamadır. $\mathrm{I}_{75}$ ve $\mathrm{I}_{50}$ 


\section{Kısıntılı Sulama Altında Hibrit Mısır Çeşitlerinin Bazı Büyüme Parametreleri Üzerine Bir Sera Çalışması}

ise tam sulamada verilen suyun sirasiyla $\% 75^{\prime} \mathrm{i}$ ve $\% 50$ 'sinin verildiği uygulamalardır. Sulama uygulamalarının yerine getirilebilmesi için denemede kullanılan toprağın bulunduğu alandan bozulmuş ve bozulmamış toprak örnekleri alınarak tarla kapasitesi ve solma noktası analizleri yapılmıştır. Analizler sonucunda toprağın TK ve $\mathrm{SN}$ düzeyleri hacimsel olarak sirasiyla \%39.91 ve \%26.08 olarak bulunmuştur. Sera denemesinde sulama uygulamaları ağırlık esasına göre uygulandığ 1 için TK ve SN'ye ait gravimetrik değerler kullanılmıştır. TK su içeriği düzeyinden itibaren bitkilerin günlük olarak tükettiği su miktarları saksıların tartımı yoluyla belirlenmiştir. Bu sebeple TK ve SN hacim ağırlı̆ğna $\left(1.35 \mathrm{~g} . \mathrm{cm}^{-3}\right)$ bölünerek sirasıly \%29.56 ve \%19.32 gravimetrik değerleri dikkate alınmıştır. Günlük olarak su kaybı ağırlık esasına göre takip edilmiş ve eksilen su istenilen seviyelere getirilmiştir.

Tartılı lizimetrelerde olduğu gibi bu saksılar tartılarak bitki su tüketimi izlenmiş ve sulama uygulamaları yapılmıştır. Sulamalardan sonra saksılardan sızma olmamıştır. Su stresi uygulanan konularda her sulamada saksılara verilecek sulama suyu miktarları aşağıdaki eşitlik ile hesaplanmıştır (Kurunç ve ark. 2011):

$$
I=\frac{W_{T K}-W_{a}}{\rho_{w}} \times \frac{P}{100}
$$

Eşitlikte I, her sulamada uygulanacak su miktarını (mililitre); $\mathrm{W}_{\mathrm{TK}}$, saksıların tarla kapasitesi ağırlıklarını (kg), Wa, sulama öncesi saks1 ağırlığını, $\rho w$, suyun yoğunluğu (1000 g $\mathrm{dm}^{-3}$ veya $\mathrm{kg} \mathrm{L}^{-1}$ ) ve $\mathrm{P}$ ise su uygulama düzeyini (\%) göstermektedir.

Deneme kurulmadan önce ilk olarak her saksının doygunluk seviyesine gelmesi için $1750 \mathrm{ml}$ su verilmiş̧ir. Toprak tavına geldiği 12 . günde her saksıya 10 adet tohum ekimi gerçekleştirilmiştir. Saksılarda 18. gün bitki çıkışları başlamıştır. 23. gün saksıda bulunan 10 adet bitkiden seyreltme yapılarak bitki sayısı dörde indirilmiştir. Tüm saksılara 12. gün itibari ile 23. güne kadar toplam $5250 \mathrm{ml}$ su verilmiş olup, bu değer ortalama 291 ml'dir. Bu günden itibaren 54. günde yapılan hasata kadar $\mathrm{I}_{100} 9182 \mathrm{ml}, \mathrm{I}_{75} 6886 \mathrm{ml}$ ve $\mathrm{I}_{50}$ için $4591 \mathrm{ml}$ su verilmiştir. Toplamda ise saksılara $\mathrm{I}_{100}, \mathrm{I}_{75}$ ve $\mathrm{I}_{50}$ uygulamalarında sirasıyla 14432 , 12136 ve $8091 \mathrm{ml} \mathrm{su} \mathrm{verilmiştir} \mathrm{(Çizelge} \mathrm{2).} 54$. günde bitki boyu tüm saksılarda tüm bitkilerde ölçülmüş ve her saksıda ortalaması bulunmuştur. $\mathrm{Bu}$ günde bitkiler hasat edilmiş ve kök ve üst aksam olmak üzere iki bölüme ayrılmıştır. Daha sonra 48 saat boyunca $70{ }^{\circ} \mathrm{C}$ 'ye ayarlanmış etüvde kurutulup bu örneklerin kuru madde ağırlıkları belirlenmiştir. Kuru ağırlıkları belirlenen örnekler agat değirmeninde ögütülerek analize hazır hale getirilmiştir.

Bitki üst aksam ve kök örneklerinde potasyum $(\mathrm{K})$, kalsiyum $(\mathrm{Ca})$, magnezyum $(\mathrm{Mg})$, yaş yakma metodu ile elde edilen süzüklerin Atomik Absorbsiyon Spektrofotometresi ile belirlenmiştir (Kacar ve İnal, 2008). Bitki örneklerinde fosfor (P) Olsen ve ark. (1954) tarafindan geliştirilen ve ekstrakt çözeltisine $(0.5$ $\mathrm{M} \mathrm{NaHCO}$ ) geçen fosforun molibdofosforik mavi renk yöntemine göre belirlenmiştir. Bitki örneklerinde Azot $(\mathrm{N})$ ise Kjeldahl destilasyon yöntemiyle yapılmıştır (Kacar ve İnal, 2008).

Sulama uygulamalarının iki farklı mısır çeşidi için izlenmiş tüm parametreler üzerinde etkilerini belirleyebilmek için tek yönlü varyans analizi (ANOVA) yapılmıştır. Konu ortalamaları arasındaki farklılikların belirlenerek gruplara ayrılmasında DUNCAN testi yapılmıştır. Yapılan bütün istatistiksel işlemlerde SPSS paket programı kullanılmıştır.

\section{Bulgular ve Tartışma \\ Sulama suyu miktarının (I) kuru madde miktarı (DM) ile olan ilişkisi}

Her bir konuya uygulanan toplam sulama suyu miktarı ve buna karşılık olarak elde edilen kuru madde miktarı değerlerinden yararlanılarak sulama-kuru madde ilişkisi regresyon analizleri ile verilmeye çalışılmıştır. Bunun sonucunda sulama ile kuru madde arasinda korelasyon katsayısı yüksek düzeyde olan doğrusal ilişkiler elde edilmiştir. Yapılan regresyon analizinde sulama suyu (I) ile kuru madde miktarı (DM) arasında; P2088 çeşidi için $\mathrm{DM}=0,0045$ I $25,019\left(\mathrm{R}^{2}=0.99\right), \mathrm{P} 1921$ ise $\mathrm{DM}=0,0045 \mathrm{I}$ 25,22 $\left(R^{2}=1\right)$ olan bir ilişki belirlenmiştir (Şekil 1). Regresyon analiz sonuçları sulama suyu ve kuru madde miktarı arasında her iki çeşit için de kuvvetli bir ilişkinin olduğunu göstermektedir. 


\section{Kısıntılı Sulama Altında Hibrit Mısır Çeşitlerinin Bazı Büyüme Parametreleri Üzerine Bir Sera Çalışması}

Çizelge 2. Deneme süresince uygulanan sulama suyu (I) miktarları, L

\begin{tabular}{lcccc}
\multirow{2}{*}{ Açıklama } & \multirow{2}{*}{ Gün } & \multicolumn{3}{c}{ Uygulanan su miktarı } \\
\cline { 3 - 5 } & & $\left.\mathbf{I}_{\mathbf{1 0 0}}\right)$ & $\mathbf{I}_{\mathbf{7 5}}$ & $\mathbf{I}_{\mathbf{5 0}}$ \\
\hline Konulu sulamalardan önce eşit su uygulamas1 & 12.gün-23. gün & 5250 & 5250 & 5250 \\
Konulu sulamalar & 24.gün-53. gün & 9182 & 6886 & 4591 \\
Toplam & & 14432 & 12136 & 8091 \\
\hline
\end{tabular}

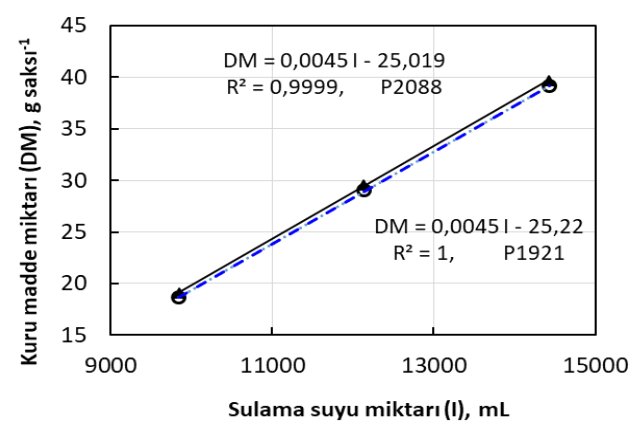

Şekil 1. Sulama suyu miktarı (I) ile Kuru madde miktarı (DM) arasındaki ilişki

Kuşçu ve ark. (2010) yürüttüğü çalışmada her iki deneme yılında, farklı düzeylerde ve fenolojik gelişme dönemlerinde uygulanan kısıntılı sulama uygulamalarının toprak üstü kuru madde miktarı üzerine etkisini \%1 olasılık düzeyinde önemli bulmuştur. Genelde uygulanan sulama suyu miktarı arttıkça toprak üstü kuru madde miktarı artmış, su kısıntısı ile kuru madde miktarı azalmıştır. Uygulanan sulama suyu (I) ile kuru madde miktarı (DM) arasinda, 2008 yılında "DM = 1.3011 I + 2062.8 ( $\left.\mathrm{R}^{2}=0.87 * *\right) "$ ve 2009 y1linda " $\mathrm{DM}=1.7095 \mathrm{I}+1501.7\left(\mathrm{R}^{2}=0.87^{* *}\right)$ " biçiminde doğrusal regresyon eşitlikleri elde edilmiştir. Benzer biçimde Igbadun ve ark. (2008) ile Mengü ve Özgürel (2008), uygulanan sulama suyu ile kuru madde miktarı arasında pozitif doğrusal bir ilișki elde etmişlerdir. Uçak (2013) ise sera koşullarında denemeye alınan P32K61, P31Y43 ve P30B74 silajlik misir çeşitlerinin farklı miktarlarda uygulanan sulama suyu miktarının kuru madde verimi ile olan ilişkisini incelemiş ve sırasıyla $\mathrm{DM}=20.57$ $\mathrm{I}+6369 \quad\left(\mathrm{r}^{2}=0.997^{* *}\right), \quad \mathrm{DM}=30.95 \quad \mathrm{I}+4340$ $\left(\mathrm{r}^{2}=0.999^{* * *}\right), \mathrm{DM}=36.14 \quad \mathrm{I}+5826 \quad\left(\mathrm{r}^{2}=0.998^{* *}\right)$ şeklinde belirlemiştir.
Farklı düzeyde sulama uygulamalarının mısır bitkisinin kuru madde miktarına etkisi

Araştırmada, farklı su düzeyi (tam ve kısıntılı sulama) uygulamalarının istatiksel olarak her iki çeşit mısır bitkisinin üst aksam ve kök kuru madde miktarı üzerinde farkl11ıklar oluşturduğu saptanmıştır (Duncan, $P \leq 0.05$ ) (Şekil 2.).

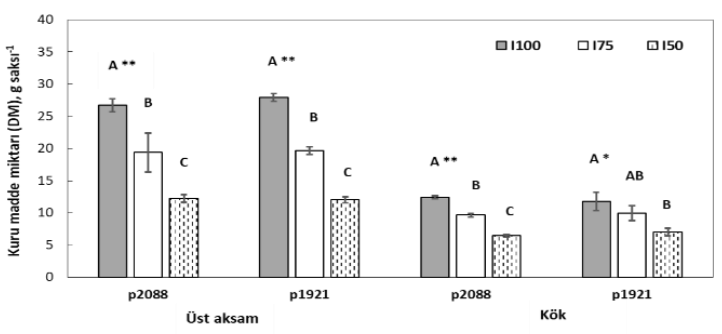

Şekil 2. Farklı sulama düzeylerinin misır bitkisinin kuru madde miktarına $\left(\mathrm{g} \mathrm{saks}^{-1}\right.$ ) etkisi (İstatistik çubukları ortalamanın standart hatas1, bar sütundaki farklı harfler ise farklı sulama düzeyleri arasındaki önemli farklılıkları (Duncan, $P \leq 0.05$ ) gösterir.)

Sulama uygulamalarının her iki mısır çeşidinde üst aksama ait kuru madde miktarı üzerine etkileri istatiksel olarak önemli bulunmuştur. P2088 çeşidinde en yüksek kuru madde miktarı $26.7 \mathrm{~g} \mathrm{saks1}^{-1}$ ile tam sulamanın yapıldığ $\mathrm{I}_{100}$ uygulamasında elde edilmiştir. Bunu $19.4 \mathrm{~g}$ saks1 $^{-1}$ ile $\mathrm{I}_{75}$ ve $12.2 \mathrm{~g} \mathrm{saks}^{-1}$ ile $\mathrm{I}_{50}$ uygulamalar1 takip etmiştir. P1921 çeşidinde ise P2088 çeşidine benzer şekilde $\mathrm{I}_{100}\left(27.9 \mathrm{~g} \mathrm{saks}^{-1}\right)>\mathrm{I}_{75}$ $\left(19.6 \mathrm{~g} \mathrm{saks}^{-1}\right)>\mathrm{I}_{50}\left(12.0 \mathrm{~g} \mathrm{saks}^{-1}\right)$ şeklinde sıralanmıştır. Her iki çeşitte uygulanan sulama miktarı arttıkça üst aksam kuru madde miktarı da artış göstermiştir. Benzer sonuçlar köke ait kuru madde verimlerinde de elde edilmiştir. P2088 çeşidinde köke ait kuru madde verimleri $\mathrm{I}_{100}$ $\left(12.5 \mathrm{~g} \mathrm{saks1}^{-1}\right)>\mathrm{I}_{75}\left(9.7 \mathrm{~g} \mathrm{saks1}^{-1}\right)>\mathrm{I}_{50}(6.5 \mathrm{~g}$ saks1 $^{-1}$ ) şeklinde sıralanırken, P1921 çeşidinde 


\section{Kısıntılı Sulama Altında Hibrit Mısır Çeşitlerinin Bazı Büyüme Parametreleri Üzerine Bir Sera Çalışması}

ise $\mathrm{I}_{100}\left(11.8 \mathrm{~g} \mathrm{saks}^{-1}\right)>\mathrm{I}_{75}\left(10.0 \mathrm{~g} \mathrm{saks1}^{-1}\right)>\mathrm{I}_{50}$ (7.1 $\left.\mathrm{g} \mathrm{saks1}^{-1}\right)$ şeklinde sıralanmıştır. Burada P1921 çeșidi için kök kuru madde gelişiminde tam sulama $\left(\mathrm{I}_{100}\right)$ uygulanan koşullardaki gelişim düzeyine I75 uygulaması ile yaklaşılabildiği görülmektedir (Şekil 2). Bu sonuçla \%25 su kısıntısına/tasarufuna gidilebileceği ortaya konulabilir.

Araştırmada ele alınan su uygulama düzeyleri bitkinin gövde ve kök aksamlarına ait kuru madde birikim miktarlarında bir değişim meydana getirmiştir. Tam sulama yapılan $\left(\mathrm{I}_{100}\right)$ misır bitkilerinin kuru madde verimleri daha yüksek elde edilmiş iken, kısıntılı sulamaya gidildiğinde azalmalar gerçekleşmiştir. $\mathrm{Bu}$ beklenen bir durumdur. Zira su tüketimi yüksek olduğundan dolay1 mısır bitkisi, etkili kök bölgesindeki tükettiği suyun tamamının tarla kapasitesine kadar sulandığında verim ve diğer verim bileşenlerinde de artış görülmektedir. Daha önce yapılan araştırmalar doğrultusunda araştırmacıların çalışmaları ile bu çalışmada elde edilen değerler arasında benzerlik bulunmaktadır (Kırnak ve ark., 2003; Dağdelen ve ark., 2006). Güneş ve Aktaş (2008), sulama suyu miktarının azalmasıyla gövde ve kök aksamına ilişkin kuru madde miktarlarında azalmalar belirlemiştir. Çalışmada en yüksek kuru madde miktarı tam sulama $\left(\mathrm{I}_{100}\right)$ konusunda elde edilirken, su stresi uygulanan $\mathrm{I}_{50}$ (tam sulamada verilen suyun \%50'sinin uygulandığı) sulama konusunda genel olarak düşük değerler elde edilmiştir. Karam ve ark. (2003) ise Lübnan'da 1998 ve1999 yıllarında yürüttükleri çalışmada damla sulama altında sulanan mısır bitkilerine ilişkin tam sulama $\left(\mathrm{I}_{100}\right)$ uygulaması ile elde edilmiş kuru madde miktarının kısıntılı sulama $\left(\mathrm{I}_{60}\right)$ uygulamasına kıyasla artış gösterdiğini bildirmişlerdir. Stone ve ark. (2001), şeker mısırı üzerindeki kısıntılı sulama uygulamalarının su kullanımı, radyasyon kullanım etkinliği, büyüme ve verim üzerine etkilerini araştırmışlardır. Kısıntılı sulama uygulamalarının verim ve kuru madde verimi üzerinde önemli ölçüde etkili olduğu saptanan araştırmada, su kısıntısıyla beraber özellikle koçan püskülü döneminden sonra radyasyon kullanım etkinliğinin azalmasıyla birlikte, kuru madde veriminin de azaldığı belirlenmiştir. Çakır (2004) su stresinin uygulanması halinde vejetatif gelişme döneminde uygulanan kısıntılara bağl1 toplam kuru madde verimini \%28-32 azalttığını belirlemiştir. Öte yandan, Mengü ve Özgürel (2008), su kisintısının olmadığ1 koşullarda yarı nemli bölgelerde yetiştirilen mısır bitkisinin sulanmasında kısıntı yapılmaması gerektiğini vurgulamışlardır.

\section{Farklı düzeyde sulama uygulamalarının mısır bitkisinin boyuna etkisi}

Daha önceki yapılmış çalışmalarda P2088 ve P1921 hibrit mısır bitki çeşitlerinde belirlenmiş bitki boyları Tohumculuk Tescil Ve Sertifikasyon Merkezi (TTSM) tarafından sirasiyla, $287 \mathrm{~cm}$ (TTSM 2016) ve $248 \mathrm{~cm}$ (TTSM 2015) olarak belirlenmiștir. Saks1 denemesi olarak yürütülen bu çalışmada bu iki çeşide farklı düzeylerde sulama $\left(\mathrm{I}_{100}, \mathrm{I}_{75}\right.$ ve $\left.\mathrm{I}_{50}\right)$ uygulanmıştır. Sulama uygulamalarının mısır çeşitlerinin boyları üzerine etkileri Şekil 3'de görülmektedir.

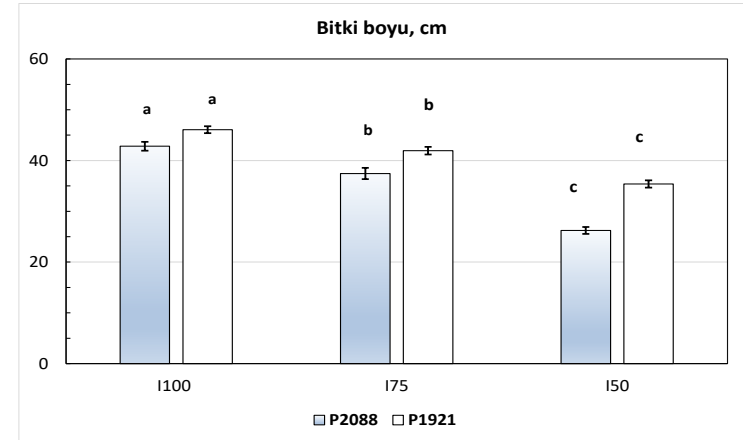

Şekil 3. Farklı sulama düzeylerinin misır bitkisinin boyuna (cm) etkisi, (İstatistik çubukları ortalamanın standart hatası, bar sütundaki farklı harfler ise farklı sulama düzeyleri arasındaki önemli farklılıkları (Duncan, $P \leq 0.05$ ) gösterir.)

P2088 ve P1921 hibrit mısır çeşidi için 42 günlük tam ve k1sitlı su uygulamas1 doğrultusunda misır bitkisinin boy uzaması üzerine etkileri istatistiksel anlamda farklılık göstermiştir (Duncan, $P \leq 0.05$ ). Her iki misır çeșidinde sulama miktarı arttıkça bitki boylarının arttığ1 görülmüştür. P2088 ve P1921 misır çeşitlerinde $\mathrm{I}_{100}$ uygulamasında sirasiyla $42.81 \mathrm{~cm}$ ve $46.08 \mathrm{~cm}$ olarak en yüksek bitki boylar1 elde edilirken, bunu $37.44 \mathrm{~cm}$ ve 41.94 $\mathrm{cm}$ ile $\mathrm{I}_{75}$ uygulaması izlemiştir. En düşük bitki 


\section{Kısıntılı Sulama Altında Hibrit Mısır Çeşitlerinin Bazı Büyüme Parametreleri Üzerine Bir Sera Çalışması}

boyları ise sirasiyla $26.23 \mathrm{~cm}$ ve $35.38 \mathrm{~cm}$ ile $\mathrm{I}_{50}$ uygulamasında elde edilmiştir. Bu çalışmadaki sonuçlara göre farklı düzeylerde uygulanan sulamanın bitki boyu üzerinde istatistiksel olarak önemli bir şekilde etkileri olmuştur. Tarla kapasitesine kadar uygulanan sulamanın bitki boyunu arttırdığına yönelik pek çok çalışma bulunmaktadır. Vural ve Dağdelen (2008) ve Kırnak ve ark. (2003) verilen su miktarındaki azalışla birlikte bitkinin gövde çapı, boyu, yaprak alan indeksi ve kuru madde miktarında önemli seviyede azalışlar yaşandığını ifade etmişlerdir. Çakır (2004) mısır bitkisinin vejetatif, tepe püskülü, koçan çıkarma ve süt olum olmak üzere 4 farklı gelişme dönemini göz önüne alarak 16 farklı kısıntılı sulama uygulamasını ele almış ve karık sulama yöntemi altında vejetatif ve tepe püskülü çıkarma dönemlerinde su stresinin uygulanması halinde bitki boyu ve yaprak alan indeksi değerlerinin azaldığını belirtmiştir. Uçak (2013) sulama suyuyla doğru orantılı olarak bitki boyunun arttığını, su kısıntılarında ise bitki boyunda düşüşler olduğunu saptamıştır. Özellikle vejetatif dönemde su kısıntısına bağlı olarak bitkinin boyca büyümesinin engellediğini bildirmiştir. Özgürel ve Pamuk (2003), Ege bölgesi koşullarında yapmış oldukları bir Çizelge 3. Üst aksamda farklı sulama düzeylerinin makro besin elementlerine (\%) etkisi

\begin{tabular}{lccccc}
\hline \multirow{2}{*}{ Uygulama } & $\mathrm{N}$ & $\mathrm{P}$ & $\mathrm{K}$ & $\mathrm{Mg}$ & $\mathrm{Ca}$ \\
\cline { 2 - 6 } & \multicolumn{5}{c}{$\mathrm{P} 2088$} \\
\hline $\mathrm{I}_{100}$ & $1.58^{\#} \pm 0.05 \mathrm{a}^{\&}$ & $0.12 \pm 0.01 \mathrm{a}$ & $3.76 \pm 0.23 \mathrm{~b}$ & $0.30 \pm 0.01 \mathrm{a}$ & $0.19 \pm 0.02 \mathrm{a}$ \\
$\mathrm{I}_{75}$ & $1.61 \pm 0.11 \mathrm{a}$ & $0.14 \pm 0.02 \mathrm{a}$ & $3.96 \pm 0.19 \mathrm{~b}$ & $0.28 \pm 0.02 \mathrm{a}$ & $0.18 \pm 0.02 \mathrm{a}$ \\
$\mathrm{I}_{50}$ & $1.79 \pm 0.19 \mathrm{a}$ & $0.15 \pm 0.04 \mathrm{a}$ & $4.77 \pm 0.16 \mathrm{a}$ & $0.28 \pm 0.01 \mathrm{a}$ & $0.18 \pm 0.02 \mathrm{a}$ \\
ANOVA & 0.502 & 0.838 & 0.012 & 0.435 & 0.826 \\
\hline & \multicolumn{5}{c}{$\mathrm{P} 1921$} \\
$\mathrm{I}_{100}$ & $1.58 \pm 0.09 \mathrm{a}$ & $0.14 \pm 0.04 \mathrm{a}$ & $4.46 \pm 0.20 \mathrm{a}$ & $0.37 \pm 0.02 \mathrm{a}$ & $0.21 \pm 0.02 \mathrm{a}$ \\
$\mathrm{I}_{75}$ & $1.71 \pm 0.04 \mathrm{a}$ & $0.13 \pm 0.01 \mathrm{a}$ & $4.96 \pm 0.23 \mathrm{a}$ & $0.38 \pm 0.02 \mathrm{a}$ & $0.25 \pm 0.01 \mathrm{a}$ \\
$\mathrm{I}_{50}$ & $1.84 \pm 0.18 \mathrm{a}$ & $0.13 \pm 0.02 \mathrm{a}$ & $4.86 \pm 0.07 \mathrm{a}$ & $0.42 \pm 0.03 \mathrm{a}$ & $0.30 \pm 0.04 \mathrm{a}$ \\
ANOVA & 0.351 & 0.905 & 0.170 & 0.270 & 0.147
\end{tabular}

$\mathrm{I}_{100}$ : Tarla kapasitesine getirilen sulama, $\mathrm{I}_{75}$ ve $\mathrm{I}_{50}$ : $\mathrm{I}_{100}$ uygulamasında verilen suyun sirasiyla \% $\% 5^{\prime} \mathrm{i}$ ve \%50'sinin uygulandığ sulama, \#: dört tekerrürün ortalaması, \pm : Ortalamanın standart hatası, \&: Bir sütundaki farklı harfler, farklı sulama düzeyleri arasındaki önemli farklılıkları (Duncan, $\mathrm{P} \leq 0.05$ ) gösterir.

P2088 ve P1921 için tüm saksılara aynı miktarda potasyum gübrelemesi uygulanmıştır. P2088 için en az düzeyde suyun verildiği $\mathrm{I}_{50}$ çalışmada en yüksek bitki boyunu $\mathrm{I}_{100}$ (tam sulama) koşulunda $235 \mathrm{~cm}$, en düşük bitki boyunu ise susuz koşulda $148 \mathrm{~cm}$ olarak tespit etmişlerdir. Bozkurt (2005), Çukurova koşullarında en yüksek bitki boyunu $271 \mathrm{~cm}$, en düşük bitki boyunu ise $253 \mathrm{~cm}$ olduğunu ifade etmiştir. Sammis ve ark. (1988) ise farklı lokasyon ve mısır çeşitlerini dikkate aldıkları çalışmada su stresi açısından bitki boyunun önemli bir göstergesi olduğunu ve bu değerin sulamanın en az yapıldığı uygulamada $269 \mathrm{~cm}$, sulamanın tarla kapasitesine kadar yapıldığ uygulamada ise $287 \mathrm{~cm}$ olarak belirlemiştir.

Farklı düzeyde sulama uygulamalarının mısır bitkisinin besin elementi konsantrasyonuna etkisi

Sulama uygulamalarının üst aksamda genelde her iki çeşit (P2088 ve P1921) için makro besin elementi üzerine etkileri istatistiksel olarak önemsiz bulunmuştur. P1921 misır çeşidi için makro elementlerden $\mathrm{N}, \mathrm{P}, \mathrm{K}, \mathrm{Mg}$ ve $\mathrm{Ca}$ istatistiksel olarak farklılık göstermemiştir. P2088 misır çeşidinde ise makro besin elementlerinden sadece potasyum konsantrasyonu sulama uygulamalarından farklı düzeyde etkilenmiştir (Çizelge 3). uygulamasında \%4.77 ile en yüksek $\mathrm{K}$ değeri elde edilmiş iken, su miktarının daha fazla uygulandiğ $I_{75}$ ve $I_{100}$ uygulamalarında ise sirasıyla \%3.96 ve $\% 3.76$ değerleri 


\section{Kısıntılı Sulama Altında Hibrit Mısır Çeşitlerinin Bazı Büyüme Parametreleri Üzerine Bir Sera Çalışması}

belirlenmiştir. P1921 çeşidinde ise üst aksamda bulunan K konsantrasyonu değerleri birbirleri ile çok yakın bulunmuştur. $\mathrm{Bu}$ değerler $\mathrm{I}_{100}, \mathrm{I}_{75}$ ve $\mathrm{I}_{50}$ uygulamaları için sırasıyla \%4.46, \%4.96 ve \%4.86 şeklinde gerçekleşmiştir. Mısır bitkisine ait sınır değer aralığı (\%3.5-\%5.0) kontrol edildiğinde (Jones ve ark., 1991) her iki çeşidin $\mathrm{K}$ konsantrasyonları yeterli aralıkta yer almıştır. Tek seferde saksilardaki topraklara uygulanan $\mathrm{K}$ gübrelemesi bitkiler için yeterli olmuştur. Misır bitkileri potasyum element gözlemleri doğrultusunda kontrol edildiğinde normal görünmekte ve maksimum verim için uygun $\mathrm{K}$ elementi içermektedir. Fakat saksı ortamında daha önce yapılan bir başka araştırmada mısır bitkisine $I_{50}$ düzeyinde sulama yapıldığında bitkinin en az düzeyde $\mathrm{K}$ elementi içerirken, $\mathrm{I}_{75}$ ve $\mathrm{I}_{100}$ sulamasinda ise bitkinin daha fazla potasyum element içeriğine sahip oldukları belirlenmiştir (Güneş ve Aktaş, 2008). Araştırmacıların yapmış olduğu bu çalışmada, söz konusu bulgular su ve kuraklık stresi altında bitkinin potasyum içeriğinin stomalarda osmoregülasyonu sağlayarak (Mengel ve Kirkby, 1987) su kullanımı yönünden düzenleyici bir nitelik taşıması nedeniyle dikkate değer bir sonuç olarak yorumlanabilmektedir. Bununla birlikte potasyumlu gübrelerin tek seferde uygulanması ve bunun neticesinde sinır değerlerini koruması, maliyet ve işgücü açısından bir kez ve ekimle verilmesinin uygun olduğu yargısını ortaya koymuştur.

Bitki dokularında bulunan besin elementi açısından en fazla bulunan element azottur ve ortalama \%1 ile \%5 değerlere sahiptir (Karnez, 2010). P2088 ve P1921 hibrit misır bitkilerine aynı miktarda uygulanan azotun farklı düzeyde su uygulamalarının üst aksam ile kaldırılan $\mathrm{N}$ içeriğine etkisi bakımından aynı grupta yer almış ve birbirine oldukça yakın olarak belirlenmiştir. Bitkinin üst aksamında sulama miktarı azaldıkça $\mathrm{N}$ konsantrasyonunun arttığ1 görülmüştür. $\mathrm{I}_{100}$ uygulamasinda en az $\mathrm{N}$ konsantrasyonu elde edilirken, $\mathrm{I}_{50}$ uygulamasinda ise en fazla $\mathrm{N}$ konsantrasyonu elde edilmiştir. P2088 ve P1921 hibrit mısır çeşitleri için tek seferde yapılan $\mathrm{N}$ (azot içerikli gübre) uygulaması $\mathrm{N}$ elementi referans değerlerinin (Jones ve ark., 1991) altında kalmıştır. Mısır bitkilerinin topraktan en çok kaldırılan ve kaybolması en çok olan elementin $\mathrm{N}$ olduğu dikkate alınırsa, bu duruma alternatif olarak ilk azotlu gübrelemeden sonra belirli bir zaman aralığ 1 içerisinde ikinci hatta üçüncü azotlu gübre uygulaması önerilebilir.

Farklı düzeyde uygulanan su miktarlarının bitki tarafindan kaldırılan P konsantrasyonuna etkisi istatiksel veriler doğrultusunda her iki çeşitte birbirine çok yakın çıkmıştır. P2088 mısır çeşidi için en yüksek $\mathrm{P}$ değeri, $\% 0.15$ ile su uygulamasının en az olduğu $\mathrm{I}_{50}$ uygulamasında elde edilmiş iken en düşük değer ise $\% 0.12$ ile $\mathrm{I}_{100}$ uygulamasında saptanmıştır. P1921 misır çeşidi için en düşük P değeri $\% 0.13$ ile kısıtlı sulamalar olan $\mathrm{I}_{50}$ ve $\mathrm{I}_{75}$ uygulamalarında elde edilirken, en yüksek P değeri ise \%0.14 ile tam sulamada belirlenmiştir. Sınır değerler altında bulunan misır bitkileri $\mathrm{P}$ noksanlığında genel olarak bitki kuru madde veriminde, ürün veriminde, fotosentez aktivitesinde, yaprak alan indeksi gibi bitki parametrelerinde düşüşe neden olduğu bilinmektedir (Colomb ve ark., 2000). Bu çalışmada farklı sulama uygulamaları, mısır bitkilerinin fosfor alım düzeylerinde önemli bir farklılık etkisi oluşturmamıştır. Denemedeki tüm misır bitkileri fosfor alımını benzer düzeyde sağlamıştır.

Magnezyum gübrelemesinin yapılmadı̆̆ çalışma koşullarında her iki çeşidin kaldırdığ 1 $\mathrm{Mg}$ konsantrasyonu her iki mısır çeşidi için de birbirine oldukça yakın bulunmuştur (Çizelge 3). P2088 misır çeşidi için Mg besin element değerleri sulama düzeyleri bakımından P1921'de gerçekleşen P konsantrasyon değerlerinin aldığı eğilimle aynı olmuştur. P1921 mısır çeşidi için en yüksek Mg besin element değeri $\% 0.42$ ile $\mathrm{I}_{50}$ uygulamasinda iken, en düşük $\mathrm{Mg}$ besin elementi değeri ise $\% 0.37$ ile $\mathrm{I}_{100}$ uygulamasında elde edilmiştir.

Kalsiyum bitki bünyesinde en fazla kullanılan üçüncü bitki besin elementidir. Bitki hücre duvarının tamamlayıcı bir parçasıdır ve bu yüzden hücre duvarı yapısını düzenleyen bitki besin elementi olarak bilinmektedir (McCauley ve ark., 2009). Aynı miktarda kalsiyum gübrelemesi altında, P2088 mısır çeşidi için en yüksek $\mathrm{Ca}$ besin element değeri $\% 0.19$ ile $\mathrm{I}_{100}$ uygulaması olmuştur. Aynı çeşitte en düşük kalsiyum besin element değeri ise $\% 0.18$ ile $\mathrm{I}_{75}$ ve $\mathrm{I}_{50}$ uygulamaları olmuştur. P1921 misır çeşidinde ise en az sulamanın yapıldığ $\mathrm{I}_{50}$ 


\section{Kısıntılı Sulama Altında Hibrit Mısır Çeşitlerinin Bazı Büyüme Parametreleri Üzerine Bir Sera Çalışması}

uygulamasında en yüksek Ca konsantrasyonu elde edilmiştir.

Makro ve mikro besin element değerleri, uygulanan gübre miktarına bağlı olabilmektedir. $\mathrm{Bu}$ araştırmada farklı gübre düzeyleri olmadığından deneme konularına göre makro elementlerin miktarlarında önemli farklılığın oluşmaması beklenen bir sonuç olabilir. Ancak, denemede farklı sulama suyu düzeyleri yer aldığ 1 için total makro elementleri miktarlarını etkileyebilir. Yapılan bir araştırmada aynı gübre miktarında kısıntılı sulama suyu koşullarında bitkideki makro ve mikro elementlerin miktarlarının artığı tespit edilmiştir (Yolcu, 2014). Bu çalışmada ise sulama uygulamalarının makro besin elementi üzerine genelinde bir farklılık bulunmamıştır.

Farklı düzeyde sulama uygulamalarının mısır bitkisinin besin elementi alımına etkisi

Bitkilerin bünyesinde bulunan besin elementlerinin bir bölümü bitki gelişiminde, bir bölümünün de metabolizma faaliyetlerinde etkin role sahip oldukları bilinmektedir. Bitkilerin besin elementlerinin alımında; bitkinin çeşidi, bitkinin yaşı, gelişme dönemi (fizyolojik dönem), besin elementinin alım gücü, çevresel faktörler vs. etkilidir (Kacar ve Katkat, 2010). Saksı denemesi olarak sera koşullarında yürütülen bu çalışmada farklı düzeyde uygulanan sulamanın misır bitkisinin toplam makro element alımı üzerine etkileri önemli bulunmuştur ( $\mathrm{p}<0.05)$ (Çizelge 4). P2088 misır çeşitlerinin $\mathrm{P}$ alımı hariç, $\mathrm{N}, \mathrm{K}, \mathrm{Mg}$ ve $\mathrm{Ca}$ alımı istatistiksel olarak farklılık göstermiştir. Her iki çeşitte toplam alınan makro besin elementlerinin tarla kapasitesine kadar sulanan $\left(\mathrm{I}_{100}\right)$ konularda bitki tarafından daha iyi alınabildiği görülmüştür. $\mathrm{Bu}$ uygulamayı sirasıyla $\mathrm{I}_{75}$ ve $\mathrm{I}_{50}$ uygulamaları takip etmiş ve sulama miktarı azaldıkça makro besin elementi alımının da azaldığg görülmüştür. P2088 çeşidi için tam sulama konusundaki makro besin elementleri $\mathrm{N}$, $\mathrm{P}, \mathrm{K}, \mathrm{Mg}$ ve $\mathrm{Ca}$ alımin konusundakine göre \%24.9, \%15.6, \%20.6, $\% 33.6, \% 24.9$ ve $\mathrm{I}_{50}$ konusundaki değerlere göre $\% 45.7, \% 37.7, \% 37.9, \% 57.6, \% 45.7$ daha yüksek gerçekleşmiş iken, bu diğer çeşit olan P1921 de $\mathrm{I}_{75}$ için \%24.4, \%33.4, \%17.9, \%16.0, $\% 24.4$ ve $\mathrm{I}_{50}$ için $\% 47.0, \% 58.7, \% 48.8, \% 43.0$, \%47.0 olarak hesaplanmıştır.
Benzer şekilde, Eissa and Negim (2019) yürüttükleri çalışmada da mısır bitkisinin $\mathrm{N}, \mathrm{P}$, $\mathrm{K}$ alımlarının sulama düzeyleri tarafından etkilendiğini $(\mathrm{p}<0,05)$ ve tam sulama $\left(\mathrm{I}_{100}\right)$ konusundaki makro element alım düzeyinin, $\mathrm{I}_{60}$ sulama konusuna göre $\% 21, \% 25$ ve $\% 21$ arttığını bulmuşlardır. Mevcut çalışma, su stresinin damla ile sulanan misir tarafindan N, P ve $\mathrm{K}$ alımını azalttığını açıkça göstermiştir. Daha önceki çalışmaların sonuçlarına göre mısır bitkilerinde $\mathrm{N}, \mathrm{P}$ ve $\mathrm{K}$ artışlarının toprak su içeriğinin artmasıyla ilişkilendirilebilir. Toprak su içeriği arttıkça $N$, P ve K'nin çözünürlüğü ve hareketliliği artar (Othman-Sanaa ve ark., 2005; İbrahim ve Kandil, 2007). Özellikle kisıntı miktarının yüksek olduğu sulamanın mısır bitkileri tarafindan $\mathrm{N}, \mathrm{P}$ ve $\mathrm{K}$ alımı üzerinde olumsuz bir etkisi olduğu belirtilmiştir (Hafiz ve ark., 2016; Karandish ve Shahnazari, 2016).

\section{Sonuçlar ve Öneriler}

Sonuçlar genel olarak değerlendirildiğinde tam sulama koşullarında $\left(\mathrm{I}_{100}\right)$ uygulanan sulamanın P2088 ve P1921 hibrit misir çeşitlerinde bitki boyunun en uzun olduğu saptanmıştır. En kısa bitki boyunu sağlayan uygulama ise en az suyun uygulandiğ ${ }_{1} \mathrm{I}_{50}$ uygulaması olmuştur. Kisıntılı sulama koşullarında bitki boyunun daha kısa kaldığ 1 saptanmıştır. Sulama miktarı azaldıkça kuru madde miktarının da azaldığ 1 belirlenmiştir. Misır bitkisinin üst aksamında yapılan analizler doğrultusunda sulama uygulamalarının P1921 mısır çeşidinde makro elementler üzerinde istatistiksel olarak önemli etkileri bulunmamıştır. P2088 misır çeşidinde ise bitkinin sadece potasyum içeriği sulama uygulamalarından önemli şekilde etkilenmiştir. $\mathrm{Bu}$ nedenle toprak analizleri sonuçlarına göre belirlenecek miktarlarda, $\mathrm{K}$ gübrelemesi önerilebilir. Bünyesinde yeteri kadar potasyuma sahip bitkiler su stresine karşı daha dayanıklıdırlar. Potasyum, su kullanımını düzenleyen bir bitki besin elementi olduğu için, kurak bölgelerde uygulanması önerilebilir. 


\section{Kısıntılı Sulama Altında Hibrit Mısır Çeşitlerinin Bazı Büyüme Parametreleri Üzerine Bir Sera Çalışması}

Çizelge 4. Farklı sulama düzeylerinin mısır bitkisinin besin elementi alımına (mg.saks1 ${ }^{-1}$ ) etkisi

\begin{tabular}{lccccc}
\hline \multirow{2}{*}{ Uygulama } & $\mathrm{N}$ & $\mathrm{P}$ & $\mathrm{K}$ & $\mathrm{Mg}$ & $\mathrm{Ca}$ \\
\cline { 2 - 6 } & $561.7^{\#} \pm 21.3 \mathrm{a}^{\&}$ & $42.4 \pm 4.3 \mathrm{a}$ & $1151.5 \pm 18.8 \mathrm{a}$ & $182.3 \pm 7.1 \mathrm{a}$ & $561.7 \pm 21.3 \mathrm{a}$ \\
$\mathrm{I}_{100}$ & $421.8 \pm 43.7 \mathrm{~b}$ & $35.8 \pm 8.3 \mathrm{a}$ & $914.2 \pm 94.0 \mathrm{~b}$ & $121.1 \pm 6.9 \mathrm{~b}$ & $421.8 \pm 43.7 \mathrm{~b}$ \\
$\mathrm{I}_{75}$ & $305.0 \pm 26.4 \mathrm{c}$ & $26.4 \pm 8.2 \mathrm{a}$ & $714.6 \pm 26.7 \mathrm{c}$ & $77.3 \pm 4.6 \mathrm{c}$ & $305.0 \pm 26.8 \mathrm{c}$ \\
$\mathrm{I}_{50}$ & 0.001 & 0.331 & 0.002 & 0.000 & 0.001 \\
ANOVA & $566.8 \pm 23.3 \mathrm{a}$ & $49.1 \pm 11.0 \mathrm{a}$ & $1349.5 \pm 56.6 \mathrm{a}$ & $190.3 \pm 9.9 \mathrm{a}$ & $566.8 \pm 23.3 \mathrm{a}$ \\
\hline \multicolumn{5}{c}{$\mathrm{P} 1921$} \\
$\mathrm{I}_{100}$ & $428.3 \pm 13.7 \mathrm{~b}$ & $32.7 \pm 1.8 \mathrm{ab}$ & $1107.8 \pm 47.8 \mathrm{~b}$ & $159.9 \pm 9.8 \mathrm{~b}$ & $428.3 \pm 13.7 \mathrm{~b}$ \\
$\mathrm{I}_{75}$ & $300.4 \pm 25.0 \mathrm{c}$ & $20.3 \pm 3.4 \mathrm{~b}$ & $690.4 \pm 22.8 \mathrm{c}$ & $108.4 \pm 3.1 \mathrm{c}$ & $300.4 \pm 25.0 \mathrm{c}$ \\
$\mathrm{I}_{50}$ & 0.000 & 0.041 & 0.000 & 0.000 & 0.000 \\
ANOVA & &
\end{tabular}

$\mathrm{I}_{100}$ : Tarla kapasitesine kadar yapılan sulama, $\mathrm{I}_{75}$ ve $\mathrm{I}_{50}: \mathrm{I}_{100}$ uygulamasında verilen suyun sirasiyla $\% 75$ 'i ve \%50'sinin uygulandığı sulama, \#: dört tekerrürün ortalaması, \pm : Ortalamanın standart hatası, \&: Bir sütundaki farklı harfler, farklı sulama düzeyleri arasındaki önemli farklılıkları (Duncan, $\mathrm{P} \leq 0.05$ ) gösterir.

Tarla kapasitesine kadar sulandığında bitkinin toplamında aldığ kısıntılı sulama uygulamalarına kıyasla daha iyi düzeyde oluşum göstermiştir. Sulama miktarı azaldıkça makro besin elementi alımı da azalmış ve $I_{50}$ uygulamasinda besin elementi alımı en düşük olmuştur. Bitkinin gelişimi için önemli olan fosfor ve potasyum elementlerinin bitki tarafindan alıminda $I_{75}$ ve $I_{100}$ uygulamaları arasında çok ciddi bir fark görülmemiştir.

$\mathrm{Su}$ kaynaklarının korunması ve sürdürülebilirliğinin sağlanması ve k1sıntılı sulama programlarının uygulanması ve su stresine dayanıklı çeşitlerin geliştirmesi ve bu çeşitlere uygun sulama olanaklarının belirlenmesi önemlidir. Bu hedef altında yapılan bu çalışmada saksıda yetiştiriciliğin mısır bitkisinin gelişimi için kısa olduğu ve özellikle kısıntılı sulama uygulamalarına ait beklenen sonuçların tam olarak görülmediği anlaşılmıştır. Ancak tam sulamanın yapıldı̆̆ $\mathrm{I}_{100}$ uygulaması ile $\mathrm{I}_{75}$ uygulaması arasında istatistiksel olarak bir farklılık olmakla birlikte tam sulamaya göre $\% 25$ tasarruf sağlayan $\mathrm{I}_{75}$ uygulamasının daha uzun yetiştiricilik periyodunda denenmesi ve uygulanması önerilebilir. Böylelikle, daha fazla alanın sulama olanağı ve bitkinin su kullanım etkinliği artabilir.

\section{Teșekkür}

$\mathrm{Bu}$ çalışma Ç.Ü. Bilimsel Araştırma Projeleri Biriminin FYL-2020-12921 No'lu Yüksek Lisans Projesinden Üretilmiştir.

\section{Kaynaklar}

Abd El Wahed, A., Sanabani, S. S., Faye, O., Pessoa, R., Patriota, J. V., Giorgi, R. R., Patel, P., Böhlken-Fascher, S., Landt, O., Niedrig, M., Zanotto, P. M. de A., Czerny, C. P., Sall, A. A., Weidmann, M. (2017) Rapid molecular detection of Zika virus in acute-phase urine samples using the recombinase polymerase amplification assay. PLoS Curr 9.

Afzal, M., Shabbir, G., Ilyas, M., Jan, S. S. A., Jan, S. A. (2018) Impact of climate change on crop adaptation: current challenges and future perspectives. Pure Appl Biol 7:965-972.

Anonim (2021a) TMMOB Ziraat Mühendisleri Odas1,

https://www.zmo.org.tr/genel/bizden_det ay.php?kod $=32780 \&$ tipi $=17 \&$ sube $=0$ (Erişim tarihi: 05.03.2021).

Anonim (2021b) Tarımsal Ekonomi Ve Politika Geliştirme Enstitüsü (TEPGE), https://arastirma.tarimorman.gov.tr/tepge (Erişim tarihi: 22.12.2021). 


\section{Kısıntılı Sulama Altında Hibrit Mısır Çeşitlerinin Bazı Büyüme Parametreleri Üzerine Bir Sera Çalışması}

Anonim (2021c) T.C. Tarım ve Orman

Bakanlı̆̆1,

https://adana.tarimorman.gov.tr/Belgeler/

SUBELER/bitkisel_uretim_ve_bitki_sagl igi_sube_mudurlugu/hububat_yetistiricili gi_ve_mucadelesi/M\%C4\%B1s\%C4\%B 1r\%20Yeti\%C5\%9Ftiricili\%C4\%9Fi.pdf (Erişim tarihi: 05.03.2021).

Bouyoucos, G. (1962) Hidrometer method improved for making particle size analysis of soil. Agron J 54:464-465.

Bozkurt, Y. (2005). Çukurova koşullarında damla yöntemiyle sulanan ikinci ürün mısır bitkisinde optimum lateral aralığının belirlenmesi. Çukurova Üniversitesi, Fen Bilimleri Enstitüsü, Tarımsal Yapılar ve Sulama Anabilim Dalı, Yüksek Lisans Tezi.

Bozkurt, Y., Yazar, A., Gencel, B., Sezen, M. S. (2006) Optimum lateral spacing for drip irrigated corn in the Mediterranean region of Turkey. Agric Water Manage 85:113120.

Chai, Q., Gan, Y., Zhao, C., Xu, H., Waskom, R. M., Niu, Y., Siddique, K. H. M. (2016) Regulated deficit irrigation for crop production under drought stress. A review. Agron Sustain Dev 36:3.

Colomb, B., Kiniry, R. J., Debaeke, P. (2000) Effect of soil phosphorus on leaf development and senescence dynamics of field-grown maize. Agron J 2:428-435.

Çakır, R. (2004) Effect of water stress at different development stages on vegetative and reproductive growth of corn. Field Crops Res 89:1-16.

Dağdelen, N., Yılmaz, E., Sezgin, F., Gürbüz, T. (2006) Water yield relation and water use efficiency of cotton (Gossypium hirsutum L.) and second crop corn (Zeamays L.) in western Turkey. Agric Water Manage 82:63-85.

Eissa, M. A., Negim, O. E. (2019) Nutrients uptake and water use efficiency of drip irrigated maize under deficit irrigation. $J$ Plant Nutr 42(1):79-88.

Fereres, E., Soriano, M. A. (2007) Deficit irrigation for reducing agricultural water use. J Exp Bot 58:147-159.
Goodwin, I., Boland, A. M. (2004) Scheduling deficit 1rrigation of fruit trees for optimizing water use efficiency. Deficit Irrigation Practices. FAO Corporate Document Repository, Rome.

Gülez, M., Şenol, S. (2002) Çukurova Üniversitesi Ziraat Fakültesi Toprak Bölümü Deneme Alanının Detaylı Toprak Etüd ve Haritalaması. Çukurova Üniversitesi Ziraat Fakültesi Dergisi, 17:103-110.

Güneş, M., Aktaş, M. (2008) Su stresinde yetiştirilen genç misır bitkisinde potasyum uygulamasının gelişme ve verim üzerine etkisi. HR. Ü. Z.F. Dergisi 12(2):33-36.

Hafiz, M. H., Wajid, F., Farhat, A., Fahad, S., Shafqat, S., Wajid, W., Hafiz, F. B. (2016) Maize plant nitrogen uptake dynamics at limited irrigation water and nitrogen. Environ Sci Pollut Res 24(3):2549-2557.

Ibrahim, S. A., Kandil, H. (2007) Growth, yield and chemical constituents of corn (Zea maize L.) as affected by nitrogen and phosphors fertilization under different irrigation intervals. $J$ Appl Sci Res 3(10):1112-20.

Igbadun, H. E., Mahoo, H. F., Tarımo, A. K. P. R., Salim, B. A. (2006) Crop water productivity of an irrigated maize crop in mkoji sub-catchment of the Great Ruaha River basin, Tanzania. Agr Water Manage 85(1-2):141-150.

Jones, J., Benton, J., Wolf, B., Mills, H. A. (1991) Plant Analysis Handbook of Plant Analysis and Interpretation Guide. MicroMacro Publishing, Georgia 30607 USA.

Kacar, B. 1994. Toprak Analizleri. Bitki ve Toprağın Kimyasal Analizleri III. A.Ü. Zir. Fak. Eğitim, Araştırma ve Geliştirme Vakfi Yayınları No:3, Ankara, 705.

Kacar, B., İnal, A. (2008) Bitki Analizleri. Nobel Yayınlar1 No: 1242.

Kacar, B., Katkat, V. (2010) Bitki Besleme. 5. Baskı, Nobel Yayın Dağıtım Tic. Ltd. Şti, Kizılay-Ankara.

Karam, F., Breidy, J., Stephan, C., Rouphael, J. (2003) Evapotranspiration, yield and water use efficiency of drip irrigated corn 


\section{Kısıntılı Sulama Altında Hibrit Mısır Çeşitlerinin Bazı Büyüme Parametreleri Üzerine Bir Sera Çalışması}

in the Bekaa Valley of Lebanon. Agric Water Manage 63(2):125-137.

Karandish, F., Shahnazari A. (2016) Soil temperature and maize nitrogen uptake improvement under partial root zone drying. Pedosphere 26(6):872-886.

Karnez, E., 2010. Aşağı Seyhan Ovasında buğday ve mısır üretim alanlarında azot bütçesine ilişkin girdi ve çıtıtların irdelenmesi. Çukurova Üniversitesi, Fen Bilimleri Enstitüsü Doktora Tezi.

Kırnak, H., Gençoğlan, C., Değirmenci, V. (2003) Harran ovası koşullarında kısıntılı sulamanın II. ürün mısır verimine ve bitki gelişimine etkisi. Atatürk Üniv Ziraat Fak Derg 34(2):117-123.

Kırtok, Y. (1998) Misır Üretimi Ve Kullanımı. Kocaoluk Basım Yayınevi, İstanbul.

Klute, A. (1986) Water retention: Laboratory methods. In: Klute, A., Ed., Methods of Soil Analysis, Part 1, Physical and Mineralogical Methods, ASA and SSSA, Madison, 635-662.

Kögler, F., Söffker, D. (2017) Water (stress) models and deficit irrigation: Systemtheoretical description and causality mapping. Ecol Model 361:135-156.

Kurunc, A., Unlukara, A., Cemek, B. (2011) Salinity and drought affect yield responseof bell pepper similarly. Acta Agric Scand B Soil Plant Sci 61:514-522.

Kuşçu, H., Karasu A., Öz, M. (2010) Bursa koşullarında damla sulamanın mısır verimine etkisi. I. Ulusal Sulama ve Tarımsal Yapılar Sempozyumu, 27-29 Mayıs 2010, Kahramanmaraş.

Lindsay, W. L., Norwell, W. A. (1978) Development of a DTPA soil test for Zn, $\mathrm{Fe}$, Mn and Cd. Soil Sci Soc Am J 42:421428.

Lopez, J. R., Winter, J. M., Elliott, J., Ruane, A. C., Porter, C. H., Hoogenboom, G. (2017) Integrating growth stage deficit irrigation into a process based crop model. Agric Forest Meteorol 243:84-92.

McCauley, A., Jones, C., Jacobsen, J. (2009) Nutrient Management. Nutrient management module 9 Montana State University Extension Service. Publication, 4449-9, p.1-16.
McLean, E. O. (1982) Soil pH and lime requirement, Methods of Soil Analysis'in İçinde, Part 2, Chemical and Microbiological Properties (Page A.L., Miller R.H., Keeney D.R., Eds.), ASA, SSSA, Agronomy No: 9. Madison, Wisconsin, USA, ss. 199-224.

Mengel, K., Kirkby, E. A. (1987) Principles of Plant Nutrition. 4th Edition Publisher, International Potash Institute, Switzerland.

Mengü, G. P., Özgürel, M. (2008) An evaluation water-yield relations in maize (Zea mays L.) in Turkey. Pak J Biol Sci 11(4):517524.

Moutonnet, P. (2004) Yield response factors of field crops to deficit irrigation. Deficit Irrigation Practices. FAO Corporate Document Repository, Rome.

Nelson, D. W., Sommers, L. E. (1982) Methods of Soil Analysis, Part 2. Chemical and Microbiological Properties, Page, A. L., Miller, R. H. Keeney, D. R. (Eds.) 2nd Ed. SSS of Am. Inc. Pub., Madison, Wisconsin.

Olsen S. R., Cole C. V., Watanabe F. S., Dean L. A. (1954) Estimation of Available Phosphorus in Soils by Extraction with Sodium Bicarbonate, U.S. Department of Agriculture, Washington DC.

Othman-Sanaa, A., Shehata, A. M. M., ElNaggar, I. M. (2005) Effect of rice straw compost and $\mathrm{N}$-fertilization on maize production and some soil physical properties. Minufiya $J$ Agric Res 30(6):1853-1863.

Özgürel, M., Pamuk, G. (2003) Mısır bitkisinin su-verim ilişkileri ve ceres-maize bitki büyüme modelinin bölge koşullarına uygunluğunun irdelenmesi üzerine bir araştırma. Proje no: TARP-2340. İzmir.

Patanè, C., Tringali, S., Sortino, O. (2011) Effects of deficit irrigation on biomass, yield, water productivity and fruit quality of processing tomato under semi-arid mediterranean climate conditions. Sci Hortic 129(4):590-596.

Pereira, L. S., Cordery, I., Iacovides, I. (2012) Improved indicators of water use performance and productivity for 


\section{Kısıntılı Sulama Altında Hibrit Mısır Çeşitlerinin Bazı Büyüme Parametreleri Üzerine Bir Sera Çalışması}

sustainable water conservation and saving. Agric Water Manage 108:39-51.

Sammis, T. W., Smeal, D., Williams, S. (1988) Predicting corn yield under limited irrigation using plant height. TRANS ASAE 31(3):830-838.

Samperio, A., Prieto, M. H., Blanco-Cipollone, F., Vivas, A., Moñino, M. J. (2015) Effects of post-harvest deficit irrigation in 'Red Beaut' Japanese plum: tree water status, vegetative growth, fruit yield, quality and economic return. Agric Water Manage 150:92-102.

Stone, P. J., Wilson, D. R., Reid, J. B., Gillespie, R. N. (2001) Water deficit effects on sweet corn. I. water use, radiation use efficiency, growth, and yield. Aust J Agric Res 52(1): 103-113.

Thomas, G. W. (1982) Exchangable cations. P. 159-165. Chemical and Microbiological properties. Agronomy Monograph No. 9 (2nd Ed) ASASSSA. Madison, Wisconsin. USA.

Uçak, A. B. (2013) Doğrudan ve geleneksel ekim yöntemlerinin ve farklı su düzeylerinin mısırın su-verim ilişkilerine etkisi. Kahramanmaraş Sütçü İmam Üniversitesi, Fen Bilimleri Enstitüsü, Biyosistem Mühendisliği Anabilim Dalı, Doktora Tezi.

Vural, Ç., Dağdelen, N. (2008) Damla sulama yöntemiyle sulanan cin misırda farklı sulama programlarının verim ve bazı agronomik özellikler üzerine etkisi. $A D \ddot{U}$ Ziraat Derg 5(2):97-104.

Yolcu, R. (2014) Diyarbakır koşullarında damla sulama ile sulanan silajlık misırda farklı sulama düzeylerinin ve farklı dönemlerde uygulanan azotlu gübrenin verim ve verim özelliklerine etkisi. Çukurova Üniversitesi, Fen Bilimleri Enstitüsü, Doktora Tezi.

Zhang, G., Liu, C., Xiao, C., Xie, R., Ming, B., Hou, P., Liu, G., Xu, W., Shen, D., Wang, K., Li, S. (2017) Optimizing water use efficiency and economic return of super high yield spring maize under drip irrigation and plastic mulching in arid areas of China. Field Crops Res 211:137146.
Zhang, X. Y., Chen, S. Y., Sun, H. Y., Pei, D., Wang, Y. M. (2008) Dry matter, harvest index, grain yield and water use efficiency as affected by water supply in winter wheat. Irrig Sci 27:1 
Kısıntılı Sulama Altında Hibrit Mısır Çeşitlerinin Bazı Büyüme Parametreleri Üzerine Bir Sera Çalışması 